\title{
Incidence, severity and management of cancer chemotherapy related oral mucositis in Eastern Cape and Western Cape
}

\begin{abstract}
Authors:
Johanna E. Maree ${ }^{1}$

Margaretha J. Combrink

Tanya de Lange ${ }^{2}$

Andrea S. Toerien ${ }^{2}$

Minette Bedeker ${ }^{2}$

Affiliations:

${ }^{1}$ Department of Nursing

Education, University of the

Witwatersrand, South Africa

${ }^{2}$ Adelaide Tambo School of Nursing Science, Tshwane University of Technology,

South Africa
\end{abstract}

Correspondence to:

Johanna Maree

Email:

lize.maree@wits.ac.za

Postal address:

7 York Road, Park Town 2194,

South Africa

Dates:

Received: 14 Oct. 2011

Accepted: 24 June 2012

Published: 04 Oct. 2012

How to cite this article: Maree, J.E., Combrink, M.J., De Lange, T., Toerien, A.S. \& Bedeker, M., 2012, 'Incidence, severity and management of cancer chemotherapy related oral mucositis in Eastern and Western Cape', Health SA Gesondheid 17(1), Art. \#632, 7 pages. http://dx.doi.org/ 10.4102/hsag.v17i1.632

(C) 2012. The Authors. Licensee: AOSIS OpenJournals. This work is licensed under the Creative Commons Attribution License.
This study explored the incidence, duration and severity of oral mucositis in patients receiving chemotherapy in the Eastern and Western Cape, how this symptom was managed and whether the patients considered the management to be effective. An exploratory, contextual, quantitative survey was conducted. The sampling method was convenience. One hundred and sixty patients were recruited, with 106, (66.3\%) participating. Data were collected by means of self-reports, using a self-administered questionnaire. Oral mucositis was a common problem, with $71.7 \%(n=76)$ reporting to have had mucositis. Pain was not effectively managed, as $69.8 \%(n=53)$ of respondents experienced pain whilst only $17.1 \%(n=13)$ reported to have used analgesics. More than half of the respondents used prescribed mouth and throat preparations, whilst $28.9 \%(n=22)$ used non-prescribed self-care measures including potentially harmful products. A significant difference was found between using non-prescribed self-care measures and the duration of oral mucositis $\left(\chi^{2}=0.81 ; p=0.01\right)$. The reported grade of mucositis did not influence the use of non-prescribed self-care measures, whilst the more pain patients experienced the less inclined they were to use these measures. The management of oral mucositis remains a challenge. Failure to palliate this distressing symptom can lead to the use of potentially harmful self-care measures.

Die studie het die insidensie, tydsduur en intensiteit van orale mukositis in Oos en Wes Kaapse pasiënte wat kankerchemoterapie ontvang verken asook hoe hierdie simptoom hanteer is en die sukses hiervan volgens die pasiënte. 'n Kwantitatiewe, ekploratiewe, kontekstuele opname is onderneem. ' $n$ Gerieflikheidsteekproef is gebruik om die deelnemers te verkry. Een hondered en sestig persone is genader en $66.3 \%(n=106)$ het aan die studie deelgeneem. Die datainsamelingsmetode was self-rapportering met behulp van ' $n$ vraelys en beskrywende statistiek is gebruik om die data te verwerk. Orale mukositis was 'n algemene probleem, aangesien $71.7 \%(n=76)$ van die respondente die simptoom ondervind het. Pyn was nie goed beheer nie, aangesien $69.8 \%(n=53)$ pyn ondervind het terwyl slegs $17.1 \%(n=13)$ aangedui het dat hulle analgetika gebruik het. Meer as die helfte van die respondente het voorgeskrewe mond en keel preparate gebruik, terwyl 28.9\% $(n=22)$ self gemedikeer het wat potensiële nadelige preparate ingesluit het. 'n Beduidende verskil is tussen die gebruik van nie voorgeskrewe medikasie en die duur van mukositis bevind $\left(\chi^{2}=0.81 ; p=0.01\right)$. Die graad van die mukositis het nie die gebruik van die self-medikasie beinvloed nie. Hoe meer pyn ondervind is, hoe minder was die neiging om die mukositis self te behandel. Die hantering van orale mukositis bly 'n uitdaging. Die onsuksesvolle palliasie van hierdie simptoom kan tot die gebruik van potensieel nadelige self-sorg maatreëls lei.

\section{Introduction}

Oral mucositis is a debilitating symptom which can have a profound effect on the quality of life of a person diagnosed with cancer (Witt 2007). Oral mucositis leads to pain which can become so severe that the patient is unable to eat or drink and can undermine the willingness to continue with chemotherapy (Douherty \& Bailey 2008). Oral mucositis can also lead to chemotherapy dose reductions, cessation of chemotherapy, hospitalisation, reliance on parenteral nutrition and even death (Sonis 2007). South African studies focussing on cancer chemotherapy-related mucositis are limited and no evidence is available of how this symptom is managed. This study therefore focused on oral mucositis, not in terms of the chemotherapy regime the patient received, but as a complication of cancer and the treatment thereof - the incidence, severity and management according to the patient.

Mucositis, or inflammation of the mucous membranes, is a common side effect for cancer patients receiving chemotherapy and/or radiotherapy and can occur anywhere along the digestive 
tract - from the mouth to the anus (Newton, Hicky \& Mars 2009). Oral mucositis is defined as mucositis of the oral and oropharyngeal mucous membranes and includes mucositis of the lips, tongue, gingiva, buccal mucosa, palate and floor of the mouth (Douherty \& Bailey 2008). Oral mucositis, a condition characterised by inflammation and ulceration of the mouth with pseudomembrane formation, affects more than $40.0 \%$ of patients receiving chemotherapy and/ or radiotherapy (Naidu, Ramana, Rani, Mohan, Suman \& Roy 2004; Volpato, Silva, Oliveira, Sakai \& Machado 2007). According to Brown, McGuire, Peterson, Beck, Dudley and Mooney (2009), 51.0\% of cancer patients receiving outpatient chemotherapy experience a sore mouth and all those receiving radiotherapy of the head and neck, including the oral cavity, will experience oral mucositis (Fulton \& Treon 2007; Cawley \& Benson 2009).

Although the incidence and severity of mucositis differs between patients and the treatment received, the risk of developing this condition increases with the number of chemotherapy cycles as well as previous episodes experienced. Chemotherapy which is cell cycle specific for the S-phase of cell division, like fluorouracil, methotrexate and Gemcitabine mercaptopurine, leads to more severe oral mucositis. It is also suspected that cancer chemotherapy administered as bolus and continuous infusion poses a greater risk for oral mucositis compared to prolonged and repetitive administration of lower doses (Naidu et al. 2004).

The pathophysiology of mucositis is not fully understood (Naidu et al. 2004) but it is thought that chemotherapy and radiotherapy-induced mucositis has two mechanisms, direct and indirect. Direct mucositis refers to the influence that chemotherapy and radiotherapy have on the maturity and cellular growth of the mucosa. The epithelial cells of the oral mucosa undergo rapid turnover - usually every seven to 14 days - and are therefore susceptible to the effects of chemotherapy. Indirect mucositis of the oral cavity refers to an invasion by Gram-negative bacteria and fugal species. Neutropenic patients are especially at risk for oral infections and when the oral cavity is infected, indirect mucositis appears. The onset of mucositis secondary to myelosuppression varies, depending on the timing of the neutrophil nadir associated with the specific chemotherapy drugs the patient receives. However, mucositis will typically develop at any point between the 10th and 21st day after receiving chemotherapy (Naidu et al. 2004) and presents as a shallow ulcer, probably caused by depletion of the basal epithelial layer leading to denudation. The healing response consists of the formation of a pseudomembrane formed by an inflammatory cell infiltrate, an interstitial exudate and the remains of cells and fibrin. This membrane is analogous to an eschar in a superficial skin lesion (Bensadoun, Magné, Marcy \& Demard 2001, in Volpato, Silva, Oliveira, Sakai \& Machado 2007).

\section{Problem statement}

According to Volpato et al. (2007), there is no consensus on the effectiveness of a variety of measures used to prevent or treat oral mucositis, therefore standard treatment does not exist. It is unclear how many South African patients experience oral mucositis as it is suspected that patients under-report their cancer and cancer treatment related symptoms. It was also not known which self-care measures patients used to manage their mucositis and how effective this was. The research question for the study was therefore: What is the incidence, duration and severity of oral mucositis in patients receiving chemotherapy in the Eastern and Western Cape, how was this symptom managed and how effective did the patients consider the management to be?

\section{Trends}

The incidence of cancer chemotherapy-related oral mucositis has been described in various studies (Chan, Chang, Molassiotis, Lee \& Lee 2003; Sonis, Elting, Keefe, Peterson, Schubert, Hauer-Jensen, Bekele, Raber-Durlacher, Donnelly \& Rubenstein 2004; Avritscher, Cooksley \& Elting 2004; Nishimura, Nakano, Ueda, Kodaira, Yamada, Mishima, Yokoyama, Terui, Takahashi \& Hatake 2010). The prevention, management, treatment and treatment guidelines for oral mucositis have also been explored, described and evaluated in Europe and countries including the United States, United Kingdom, Japan and Europe (Eilers \& Million 2007; Harris, Eilers, Harriman, Cashavelly \& Maxwel 2008; Clarkson, Worthington, Furness, McCabe, Khalid \& Meyer 2010; Feller, Essop, Wood, Khammasisa, Chikte, Meyerov \& Lemmer 2010; Wu, Beale \& Ma 2010; Eilers \& Million 2011; Worthington, Clarkson, Bryan, Furness, Glenny, Littlewood, McCabe, Meyer \& Khalid 2011). How patients experienced oral mucositis have been explored and described by Chen (2008) and Brown, Beck, Peterson, McGuire, Dudley \& Mooney (2009) and the impact of severe oral mucositis on the function and quality of life by Cheng (2010). Sieracki, Johannik, Kopaczewski \& Hubert (2009) described the development and implementation of a patient-centred oral care protocol whilst Kearney, Miller, Maguire, Dolan, MacDonald, McLeod, Maher, Sinclair, Norrie \& Wengström (2008) assessed a nursing intervention aimed at the reduction of chemotherapy-related symptoms including oral problems. The South African literature describes the pathobiology, epidemiology and management of chemotherapy and radiotherapy-related oral mucositis (Feller, Essop, Wood, Khammasisa, Chikte, Meyerov \& Lemmer 2010) and a nursing management approach relating to oral mucositis (Robinson 2008).

\section{Objectives of the study}

Little is known about oral mucositis as side effect of South African patients receiving cancer chemotherapy as no literature investigating this side effect in the specific setting could be found. The objectives of the study were to explore the incidence, duration and severity of oral mucositis in cancer patients receiving chemotherapy in the Eastern and Western Cape; how this symptom was managed and how effective the patients considered the management to have been. 


\section{Contribution to field}

The current study provides baseline data allowing reflective practice in terms of how this side effect is currently prevented and managed. The study furthermore provides a baseline allowing comparative studies in terms of the application of evidence based practice and interventions to improve disease and treatment outcomes of patients suffering from cancer.

\section{Research methods and design Strategy and setting}

An exploratory strategy was used for this study. The setting was a private oncology practice based in Cape Town, South Africa. This practice forms part of the private health care system and has various satellite practices in Western and Eastern Cape. Cancer patients with a wide variety of diagnoses are treated at this practice, most commonly on an outpatient basis. Modern equipment and technology are used and patients are managed in a holistic manner by a multi-professional team.

\section{Design and recruitment strategy}

A quantitative survey was conducted and 160 patients were recruited but $106(n=106), 66.3 \%$, participated. The inclusion criteria were older than 18 years, treated with chemotherapy and willing to participate. Sampling was convenience as all patients 18 years and older, receiving chemotherapy and willing to participate were included.

\section{Survey instrument}

To enable data collection a self-administered questionnaire based on literature and expert opinion was developed. The questionnaire consisted of two sections and contained both open-ended and closed-ended questions. Section A allowed the gathering of general information whilst Section B focused on oral mucositis. Mucositis related questions concentrated on the number of times the respondent experienced this symptom, the severity, the pain experienced, how this symptom was managed and how effective the respondent considered the management to have been. The oral toxicity scale of the World Health Organization was used as the grading scale. The questionnaire was pre-tested using the first 10 respondents $(n=10)$, with no changes made as respondents raised no queries. The data gathered during the pre-test forms part of the final data.

\section{Data collection and analyses}

The data were collected during respondents' scheduled appointments in August and September 2010. The field worker explained the purpose of the study and informed consent; handed the questionnaire to the respondent and requested the respondent to hand it back once completed. No time limit applied. Completed questionnaires were numbered and sealed in an envelope. The data were entered onto an Excel spreadsheet and analysed by means of the SPSS 14 computer programme. The data are presented as descriptive statistics. The chi-square was used for secondary data analyses.

\section{Results}

The median age of respondents was 60 years with the average age 55.8 years. Females were in the majority (59.4\%) with the most common diagnosis being breast cancer. The general characteristics of the respondents are outlined in Table 1.

\section{Incidence, duration and severity}

When asking respondents whether they had ever had oral mucositis $71.7 \%(n=76)$ indicated they had this complication, whilst 28.3\% $(n=30)$ denied ever having it. When asked how many times they had had oral mucositis, $46.1 \%$ indicated once or twice, whilst $19.7 \%$ indicated three to five times, $9.2 \%$ did not know whilst the rest (25\%) indicated more than five times. When respondents were asked how long their mouths were sore, the number of days ranged from one to 14 (Table 2); one respondent $(0.9 \%)$ indicated her mouth was

TABLE 1: General characteristics ( $n=106)$.

\begin{tabular}{|c|c|c|}
\hline Variable & $n$ & $\%$ \\
\hline \multicolumn{3}{|l|}{ Age group } \\
\hline $18-19$ & 1 & 0.9 \\
\hline $20-29$ & 4 & 3.8 \\
\hline $30-39$ & 7 & 6.6 \\
\hline $40-49$ & 20 & 18.9 \\
\hline $50-59$ & 18 & 17.0 \\
\hline $60-69$ & 44 & 41.5 \\
\hline 70 and older & 12 & 11.3 \\
\hline \multicolumn{3}{|l|}{ Gender } \\
\hline Male & 43 & 40.6 \\
\hline Female & 63 & 59.4 \\
\hline \multicolumn{3}{|l|}{ Marital status } \\
\hline Married civil & 77 & 72.6 \\
\hline Married traditional & 4 & 3.8 \\
\hline Single & 12 & 11.3 \\
\hline Widowed & 4 & 3.8 \\
\hline Divorced & 9 & 8.5 \\
\hline \multicolumn{3}{|l|}{ Diagnosis } \\
\hline Breast cancer & 28 & 26.4 \\
\hline Cervical cancer & 4 & 3.8 \\
\hline Colorectal cancer & 21 & 19.8 \\
\hline Liver cancer & 5 & 4.7 \\
\hline Lung cancer & 9 & 8.5 \\
\hline Lymphoma & 6 & 5.7 \\
\hline Ovarian cancer & 10 & 9.4 \\
\hline Prostate cancer & 4 & 3.8 \\
\hline Other & 19 & 17.9 \\
\hline
\end{tabular}

TABLE 2: Duration of a sore mouth $(n=76)$.

\begin{tabular}{lll}
\hline Days & $\boldsymbol{n}$ & $\mathbf{\%}$ \\
\hline 1 & 3 & 3.9 \\
2 & 11 & 14.5 \\
3 & 16 & 21.1 \\
4 & 10 & 13.2 \\
5 & 7 & 9.2 \\
6 & 1 & 1.3 \\
7 & 9 & 11.8 \\
10 & 6 & 7.9 \\
14 & 5 & 6.6 \\
Could not tell & 7 & 9.2 \\
Permanently & 1 & 1.3 \\
\hline Total & 76 & 100 \\
\hline
\end{tabular}


'permanently' sore, whilst seven $(9.2 \%)$ could not tell. The average number of days respondents experienced a sore mouth was 5.1 days and the median 4 days.

The grading scale of the WHO was used when asking respondents $(n=76)$ to describe their mouths when at their worst. Two (2.9\%) did not know, whilst $29.9 \%$ graded their mucositis as Grade 1, $40.8 \%$ as Grade 2, 25\% as Grade 3 and $2.9 \%$ as Grade 4 . Respondents were also asked to quantify the pain they experienced when their mouths were most painful and a numerical scale was provided for this purpose. Most $(69.8 \% ; n=53)$ indicated they experienced pain and the rating varied from 0 , having no pain, to 10 , worst possible pain. A comparison between the reported grade of mucositis and pain level is presented (Table 3).

\section{Management}

To determine how the mucositis was managed, three themes were explored - disclosure, prescribed medicine and self medication. Respondents were asked whether they reported the oral mucositis, to whom they reported it to and whether they were open and honest about their experience. The majority $(73.7 \%)$ indicated they told a health care professional about their oral mucositis, whilst $21.5 \%$ told no one, and $5.3 \%$ did not answer the question. A greater percentage of females compared to males ( $25.5 \%$ vs $13.8 \%$ ) did not tell either the nurse or the oncologist of their mucositis. More than half (56.3\%) of the total number of respondents who did not disclose their mucositis $(n=16)$ had moderate pain, whilst the rest (43.7\%) experienced mild pain.

Not all respondents were prepared to disclose to whom they reported the mucositis as $25.0 \%$ did not answer the question; however, $17.1 \%$ informed a nurse, $40.8 \%$ the doctor and the rest $(17.1 \%)$ told both the nurse and the doctor. When exploring whether respondents were open and honest about what they disclosed, the majority (55.2\%) indicated they told the doctor and/or nurse exactly how they experienced the mucositis, $6.6 \%$ indicated they told the doctor and/or nurse but did not tell them how bad it really was, whilst $7.9 \%$ indicated to have only mentioned it but did not discuss it. The rest (30.3\%) did not answer the question. No respondent selected the option 'I told them, but it made it worse than it was for me'.

More than half of the respondents who had had a sore mouth $(56.6 \% ; n=43)$ indicated they used prescribed mouth and throat preparations. Approximately 20.6\% were unable to name the medication. However, Benzidamine oral rinse was used by $47.1 \%$ alone or in combination with nystatin $(38.2 \%)$ and miconazole $(20.6 \%)$. Triamcinolone acetonide ointment was used by $8.8 \%$. Respondents were asked to indicate on a numerical scale how effective they found the prescribed medication. Answers varied from 0 , not effective at all to 10 extremely effective could not be better, with the average being 7 .

Respondents were also asked whether they used any selfcare measures not prescribed by the oncologist. More than one quarter of respondents $(28.9 \% ; n=22)$ confirmed this. The duration of mucositis played a role in using nonprescribed self-care measures as a significant difference was found between the group who reported to have had mucositis for longer than 7 days and those whose mucositis lasted 7 days and less $\left(\chi^{2}=0.81 ; p=0.01\right)$. The reported grade of mucositis did not influence the use of non-prescribed self-care measures, as less than $50.0 \%$ of respondents with Grade 2 and 3 mucositis and more than $50.0 \%$ of respondents with Grade 1 and 4 mucositis used these measures. A greater percentage of respondents with mild pain $(56 \% ; n=14)$ than those with moderate pain $(51.2 \% ; n=18)$ reported the use of non-prescribed self-care measures, whilst only $20.0 \%$ of those with severe pain $(n=10)$ reported using these measures.

Non-prescribed self-care measures consisted mainly of oral rinses with bicarbonate of soda (19.1\%) followed by oral rinses with salt water $(14.3 \%)$. Other self-care measures included oral rinses with a combination of salt and bicarbonate of soda, oral rinses with Epsom salts, mouthwash containing calendula and tea-tree oil, Zam-Buk, glycerine, cold pressed sunflower oil, baby teething oral gels, commercial mouthwash, and probiotics. The use of these products were mostly recommended by a family member or friend $(28.5 \%)$, pharmacist $(23.8 \%)$ or nurse $(23.8 \%)$; the rest used their own initiative or did not disclose the source of advice. Once again, a numerical scale was used for respondents to indicate the efficacy of their self-care measures, with answers ranging from three to 10, with the average being 7.4.

Finally, respondents were asked whether they took analgesics to alleviate the pain caused by the oral mucositis. Only $17.1 \%$ of the total number of respondents $(n=76)$ indicated that they did. When comparing the use of analgesics with the pain level, it was found that none of the respondents who experienced mild pain $(n=25)$ took an analgesic; $23.1 \%$ who had moderate pain $(n=39)$ took analgesics; whilst $40.0 \%$ who

TABLE 3: Severity of oral mucositis and pain experienced $(n=74)$.

\begin{tabular}{|c|c|c|c|c|c|c|c|c|c|}
\hline \multirow[t]{2}{*}{ Grade } & \multirow[t]{2}{*}{ Description } & \multirow[t]{2}{*}{$N$} & \multicolumn{2}{|c|}{ Mild pain } & \multicolumn{2}{|c|}{ Moderate pain } & \multicolumn{2}{|c|}{ Severe pain } & \multirow[t]{2}{*}{ Average pain score } \\
\hline & & & $n$ & $\%$ & $n$ & $\%$ & $n$ & $\%$ & \\
\hline 1 & Red and painful but no sores (ulcers) & 22 & 22 & 100 & 0 & 0 & 0 & 0 & 2.3 \\
\hline 2 & $\begin{array}{l}\text { Sores (ulcers) with or without redness. Could eat } \\
\text { solid food }\end{array}$ & 31 & 3 & 9.7 & 28 & 90.3 & 0 & 0 & 5.3 \\
\hline 3 & $\begin{array}{l}\text { Sores (ulcers) with or without redness. Could not } \\
\text { eat solid food but could swallow liquids }\end{array}$ & 19 & 0 & 0 & 11 & 57.9 & 8 & 42.1 & 7.4 \\
\hline 4 & Could neither eat or drink & 2 & 0 & 0 & 0 & 0 & 2 & 100 & 8.8 \\
\hline
\end{tabular}


experienced severe pain $(n=10)$ used analgesics. Over-thecounter as well as prescribed analgesics were used (Table 4).

When the respondents were asked how effective the analgesics were in relieving their pain, they could choose from four options: 'The medication worked: (1) well, it took the pain away completely; (2) well, I only had slight pain; (3) not so well, I still had pain; (4) not well at all, it made no difference to the pain'. Slightly more than one fifth $(22.2 \%)$ of respondents who had moderate pain found the analgesic they used to be very effective, $66.7 \%$ reported it as effective and $11.1 \%$ as not so effective, as they still experienced pain. Of the respondents who had severe pain $(n=4)$, the majority $(75.0 \%)$ indicated that the pain medication was not so effective, as they still experienced pain, whilst one respondent $(25.0 \%)$ indicated the medication worked well, as she only had slight pain.

\section{Ethical consideration}

The ethical principles outlined in the Belmont Report (Polit \& Beck 2010), of beneficence, respect for human dignity, justice, confidentiality and debriefing, were followed. The study was explained to all patients who met the entrance requirements and only those who volunteered were entered. Informed consent was discussed with respondents and respondents consented to participate in the study by completing the questionnaire. Anonymity and confidentiality were ensured by numbering the questionnaires sequentially. After completing the questionnaire, time was allowed for them to raise queries. Furthermore, the research proposal was peer-reviewed by the Departmental and Faculty Research and Innovations Committees of the Tshwane University of Technology and approved by the Ethics Committee of the same university as well as the Ethics Committee of the private oncology practice.

\section{Validity and reliability}

The following measures were taken to increase the validity and reliability of the findings:

- The questionnaire was formulated and specifically planned to explore oral mucositis in patients receiving out-patient chemotherapy.

TABLE 4: Pain level and analgesics used $(n=13)$.

\begin{tabular}{|c|c|c|}
\hline Pain level & $n$ & $\%$ \\
\hline \multicolumn{3}{|l|}{ Moderate pain $(n=9)$} \\
\hline Paracetamol & 1 & 11.1 \\
\hline $\begin{array}{l}\text { Combination drug: ibuprofen } 200 \mathrm{mg} \text {, paracetamol } 300 \mathrm{mg} \text {, } \\
\text { codeine phosphate } 10 \mathrm{mg}\end{array}$ & 4 & 44.4 \\
\hline $\begin{array}{l}\text { Combination drug: paracetamol } 320 \mathrm{mg} \text {, codeine phosphate } 8 \mathrm{mg} \text {, } \\
\text { caffeine Anhydrous } 32 \mathrm{mg} \text {, meprobamate } 150 \mathrm{mg}\end{array}$ & 3 & 33.3 \\
\hline $\begin{array}{l}\text { Combination drug: paracetamol } 500 \mathrm{mg} \text {, d-propoxyphene } \\
\text { napsylate } 50 \mathrm{mg} \text {, dyphenhydramine } \mathrm{HCl} 5 \mathrm{mg} \text {, caffeine } 50 \mathrm{mg}\end{array}$ & 1 & 11.1 \\
\hline \multicolumn{3}{|l|}{ Severe pain $(n=4)$} \\
\hline Paracetamol & 1 & 25.0 \\
\hline Aspirin & 1 & 25.0 \\
\hline $\begin{array}{l}\text { Combination drug: tramadol hydrochloride } 37.5 \mathrm{mg} \text {, } \\
\text { paracetamol, } 325 \mathrm{mg}\end{array}$ & 1 & 25.0 \\
\hline Tilidine $\mathrm{HCl}$ & 1 & 25.0 \\
\hline Total & 13 & - \\
\hline
\end{tabular}

- The questionnaire was pre-tested before data gathering commenced.

- Oral mucositis was graded according to the Oral Toxicity Scale of the World Health Organization (Quinn, Stone, Uhlenhopp, McCann \& Blijlevens 2007).

- Data were gathered at venues and times specifically planned for data gathering.

- To create trust, registered nurses practicing at the various oncology practices were trained to gather the data.

- The lead researcher is an oncology nurse with more than 20 years experience in oncology nursing, and the co-workers who did the fieldwork are registered nurses engaged in a post-registration learning programme in oncology nursing.

\section{Discussion}

The study provided evidence that oral mucositis is a common complication, with most patients reporting having had mucositis on more than one occasion. This incidence level (71.7\%) was slightly lower than the $75.4 \%$ reported by Chen (2008), but higher than the $32.0 \%$ reported by Goldberg, Chiang, Selina \& Hamarman (2004) and the 51.0\% reported by Elting, Cooksley, Chambers, Cantor, Manzullo \& Rubenstein (2003). The re-occurrence of oral mucositis is not unique, as Elting et al. (2003) reported that $53.0 \%$ of their sample had previously had this complication. In the current study, most patients $(89.4 \%)$ reported that their mucositis lasted 14 days or less, a finding supported by Cheng (2006), who reports that more than $90.0 \%$ of patients will recover from oral mucositis within one to two weeks. One respondent's statement that her mouth was 'permanently' sore could raise questions, but in their study interpreting patients' experience of oral mucositis, Borbasi, Cameron, Quested, Olver, To \& Evans (2002) found that oral symptoms have the potential to persist and become chronic, and that it does not mean that 'all is fine' once the ulcers have healed, allowing the patient to swallow. Although these authors did not describe pain as part of the chronic problems associated with oral mucositis, the current study provides evidence of this.

As illustrated in this study, pain is a problem associated with oral mucositis. Feller et al. (2010) support this finding, stating that oral mucositis is 'almost always' painful, whilst Elting et al. (2003) state that pain 'frequently' accompanies oral mucositis. Interestingly, patients rated their pain according to the way they graded their mucositis. This finding alleviates the fears of some nurses who, according to Maree (2009), still believe cancer patients over-exaggerate the level of pain they experience.

The finding that some patients would not report their oral mucositis, or how bad it really was for them, reiterates the importance of assessment, as patient problems cannot be addressed without it. Farrell et al. (2005) support this statement with their finding that nurses are unable to identify $80.0 \%$ of the concerns of cancer patients undergoing chemotherapy. Pain, especially severe pain, was not effectively managed. Being unable to prescribe medication cannot serve as justification for 
this situation, as the advocacy role of the nurse requires acting as a 'go-between' for the patient and doctor (Anstay 1997).

One interesting finding is the fact that the more pain the patients experienced, the less inclined they were to use selfcare measures. The reason for this is unclear, especially in the light of pain not being managed effectively, and should be explored. Symptom management is essential for patients with mucositis and nurses should use their skills to intervene before the situation becomes difficult (Borbasi et al. 2002).

Not all patients found the prescribed oral and throat preparations helpful, and some reverted to self-care measures, which they found to be more helpful. Köstler, Hejna, Wenzel \& Zielinski (2001), as well as Cheng (2006), support this finding by stating that no single uniformly efficacious agent or intervention has been identified to manage chemotherapy-related oral mucositis which could serve as evidence-based standard therapy. However, there is reasonable evidence that using Benzadimine oral rinse, a nonsteroid anti-inflammatory drug seems efficacious in reducing ulceration (Sonis, Clairmont, Lockhart \& Connolly 1985). Although topical Triamcinolone is used for apthous ulcers (Flint 2006), evidence is lacking of its efficacy, specifically in chemotherapy-related oral mucositis.

To assume that patients suffering from cancer do not use nonprescribed self-care measures and medication is unrealistic and the study provides evidence that patients do indeed use non-prescribed self-care. The danger is the potential harm of these measures. A saline solution ( $0.9 \%$ sodium chloride) is non-irritant and might be the least harmful mouthwash available (Miller \& Kearney 2001); using sodium bicarbonate is also part of recommended practice (The Johanna Briggs Institute 2010) but it is unclear whether the patients in this study used the correct formula to constitute the solution. Commercial mouthwashes may contain oils, antiseptics, alcohol, astringents and aromatic substances which have the potential to irritate the mucosa and lead to hypersensitive mucositis. Using glycerine or glycerine-based products could also be harmful, as they dry the oral mucosa (Kirshnasamy 1995, in Atkinson \& Virdee 2001). Evidence is not available as to the efficacy or potentially harmful effects of other products used topically or as a mouthwash.

\section{Limitations of the study}

This study has several limitations. The study was conducted in specific private cancer care settings and the results are therefore only applicable to this specific patient population. Convenience sampling was used for sample selection, which could have lead to bias. Using a questionnaire as a datacollection instrument allowed the respondents to not answer all the questions and furthermore they were familiar with the investigators and could have provided socially acceptable answers. Respondents did not necessarily have oral mucositis during the gathering of the data and recall bias might have been possible.

\section{Recommendations}

Unfortunately, research to date has not been able to identify a universal effective intervention for the prevention and treatment of mucositis (Rubenstein, Peterson, Schubert, Keefe, McGuire, Epstein, Elting, Fox, Cooksley \& Sonis 2004; Feller et al. 2010). Using a standard approach based on the current evidence is therefore recommended. A standard approach could include a baseline assessment consisting of a risk assessment and oral inspection before any patient commences chemotherapy, ongoing assessment, an oral mucositis prevention protocol as well as a protocol for the management of this side-effect (The Johanna Briggs Institute 2010). Once standard care plans are used, individual care plans could be developed to ensure the best outcomes for each patient and allow the development of practice-based evidence. Furthermore, nurses should fulfil their advocacy role to ensure that appropriate analgesics, informed by the patient's reported pain level, are prescribed for every patient suffering from oral mucositis.

\section{Conclusion}

The management of oral mucositis remains a challenge. Failure to palliate this distressing symptom can lead to the use of potentially harmful self-care measures. This may be avoided by thorough assessment, the implementation of standard care and developing individualised care plans to improve patient outcomes.

\section{Acknowledgements}

The Adelaide Tambo School of Nursing Science funded the project. Mrs F. Johannes and S. Nskosana assisted with the gathering of the data.

\section{Competing interests}

The authors declare that they have no financial or personal relationship(s) which may have inappropriately influenced them in writing this article.

\section{Authors' contributions}

J.E. Maree (University of the Witwatersrand) was the project leader and wrote the manuscript. M.J. Combrink, T. de Lange and A.S. Toerien (Tshwane University of Technology) assisted with the data gathering and reviewed the manuscript.

\section{References}

Anstay, S., 1997, 'Communication', in J. Penson \& R. Fisher, (eds.), Palliative care for people with cancer, pp. 246-168, Arnold, London.

Atkinson, J. \& Virdee, A., 2001, 'Promoting comfort for patients with symptoms other than pain', in: S. Kinghorn \& R. Gamlin, (eds.), Palliative nursing: Bringing comfort and hope, pp. 43-62, Bailliere Tindall, Edinburgh.

Avritscher, E., Cooksley C. \& Elting, L.,2004, 'Scope and epidemiology of cancer therapy-induced oral and gastrointestinal mucositis', Seminars in Oncology Nursing 20, 3-10, viewed 7 March 2012, from http://dx.doi.org/10.1053/j. soncn.2003.10.002, PMid:15038511.

Borbasi, S., Cameron, K., Quested, B., Olver, I., To, B. \& Evans, D., 2002, 'More than a sore mouth: Patient's experience of oral mucositis', Oncology Nursing Forum 29 1051-1057, viewed 12 July 2011, from http://dx.doi.org/10.1188/02.ONF.10511057. PMid:12183754. 
Brown, C., Beck, S., Peterson, D., McGuire, D., Dudley, W. \& Mooney, K., 2009 'Patterns of sore mouth in outpatients with cancer receiving chemotherapy' Supportive Care in Cancer 17, 413-428, viewed 8 February 2012, from http:// Supportive Care in Cancer 17, 413-428, viewed 8 February
dx.doi.org/10.1007/s00520-008-0509-y, PMid:18839221.

Chan, C., Chang, A., Molassiotis, A., Lee, I. \& Lee, G., 2003, 'Oral complications in Chinese cancer patients undergoing chemotherapy', Supportive Care in Cancer $11,48-55$.

Cawley, K. \& Benson, L., 2009, 'Mucositis', in S. Newton, M. Hickey, J. Marrs, (eds.), Mosby's oncology nursing advisor. A comprehensive guide to clinical practice, $\mathrm{pp}$. 374-375, Mosby St Louis.

Chen, H.M., 2008, 'Patient's experiences and perceptions of chemotherapy-induced oral mucositis in a day unit', Cancer Nursing 31,363-369, viewed 12 July 2011 , from http://dx.doi.org/10.1097/01.NCC.0000305762.89109.29, PMid:18772661.

Cheng, K., 2006, 'Oral complications in patients with cancer', in N. Kearney \& A Richardson, (eds.), Nursing patients with cancer, Principles and practice, pp. 575600 , Elsevier, Edinburgh.

Clarkson, J., Worthington, H., Furness, S., McCabe, M., Khalid, T. \& Meyer, S., 2010 'Interventions for treating oral mucositis for patients with cancer receiving treatment', Cochrane Database of Systemic Reviews 8.

Douherty, L. \& Bailey, C., 2008, 'Chemotherapy', in J. Corner \& C. Bailey, (eds.), Cancer nursing: Care in context, pp. 267-316, Blackwell, Oxford.

Eilers, J. \& Million, R., 2007, 'Prevention and management of oral mucositis in patients with cancer', Seminars in Oncology Nursing 23, 201-212. http://dx.doi. org/10.1016/j.soncn.2007.05.005, PMid:17693347

Eilers, J. \& Million, R., 2011, 'Clinical update: Prevention and management of ora mucositis in patients with cancer', Seminars in Oncology Nursing 27, e1-e16, viewed 7 February 2012, from http://dx.doi.org/10.1016/j.soncn.2011.08.001, PMid:22018411

Elting, L., Cooksley, C., Chambers, M., Cantor, S., Manzullo, E. \& Rubenstein, E., 2003 'The burdens of cancer therapy', Cancer 98, 1531-1539, viewed 12 July 2011 from http://dx.doi.org/10.1002/cncr.11671, PMid:14508842

Farrell, C., Heaven, C., Beaver, K. \& Maguire, P., 2005, 'Identifying the concerns of women undergoing chemotherapy', Patient Education and Counseling 56, 72 77, viewed 15 April 2011, from http://dx.doi.org/10.1016/j.pec.2003.12.008 PMid:15590225

Feller, L., Essop, R., Wood, N., Khammasisa, R., Chikte, U., Meyerov, R. \& Lemmer J., 2010, 'Chemotherapy and radiotherapy-induced oral mucositis: pathology, epidemiology and management', SADJ: Journal of the South African Dental Association 65, 372-374. PMid:21133051

Flint, S., 2006, 'Oral ulceration: GP guide to diagnosis and treatment', Prescriber 17, 32-48, viewed 13 July 2011, from http://dx.doi.org/10.1002/psb.346

Fulton, J. \& Treon, M., 2007, 'Oral mucositis', in M. Langhorne, J. Fulton, S. Otto, (eds.), Oncology nursing, pp.505-523, Mosby, St Louis.

Goldberg, S., Chiang, L., Selina, N. \& Hamarman, S., 2004, 'Patient perceptions about chemotherapy-induced oral mucositis: Implications for primary/secondary prophylaxis strategies', Supportive Care in Cancer 12, 526-530, viewed 12 July 2011, from http://dx.doi.org/10.1007/s00520-004-0640-3, PMid:15150704

Harris, D., Eilers, J., Harriman, A., Cashavelly, B. \& Maxwell, C., 2008, 'Putting Evidence Into Practice ${ }^{\oplus}$ : Evidence-Based Interventions for the Management of Oral Mucositis', Clinical Journal of Oncology Nursing 12, 141-152, viewed 7 February 2012, from http://dx.doi.org/10.1188/08.CJON.141-152, PMid:18258584

Kearney, N., Miller, M., Maguire, R., Dolan, S., MacDonald, R., McLeod, J., Maher, L., Sinclair, L., Norrie, J. \& Wengström, Y., 2008, 'WISECARE+: Results of a European study of a nursing intervention for the management of chemotherapy-related symptoms', European Journal of Oncology Nursing 12, 443-448.
Kostler, W., Hejna, M., Wenzel, C. \& Zielinski, C., 2001, 'Oral mucositis complicating chemotherapy and/or radiotherapy: Options for prevention and treatment', CA A Cancer Journal for Clinicians 51, 290-315.

Maree, J., 2009, 'An investigation into registered nurse awareness of and practice related to cancer pain', Journal of Pain Management 3, 53-62.

Miller, M. \& Kearney, N., 2001, 'Oral care for patients with cancer: A review of the literature', Cancer Nursing 24, 241-254, viewed 14 July 2011, from http://dx.doi. org/10.1097/00002820-200108000-00001, PMid:11502032

Naidu, M., Ramana, G., Rani, P., Mohan, I., Suman, A. \& Roy, P, 2004, 'Chemotherapyinduced and/or radiation therapy-induced oral mucositis-complicating the treatment of cancer', Neoplasia 6, 423-431, viewed 14 July 2011, from http:// dx.doi.org/10.1593/neo.04169, PMid:15548350, PMCid:1531648

Newton, S., Hickey, M. \& Marrs, J., 2009, Mosby's oncology nursing advisor, St Louis, Mosby.

Nishimura, N., Nakano, K., Ueda, K., Kodaira, M., Yamada, S., Mishima, Y., Yokoyama, M., Terui, Y., Takahashi, S. \& Hatake, K., 2011, 'Prospective evaluation of incidence and severity of oral mucositis induced by conventional chemotherapy in solid tumors and malignant lymphomas', Supportive Care in Cancer 1-7.

Quinn, B., Stone, R., Uhlenhopp, M., McCann, S. \& Blijlevens, N., 2007, 'Ensuring accurate oral mucositis assessment in the European Group for Blood and Marrow Transplantation Prospective Oral Mucositis Audit', European Journal of Oncology Nursing 11, S10-S18, viewed 15 April 2011, from http://dx.doi.org/10.1016/ S1462-3889(07)70003-0

Rubenstein, E., Peterson, D., Schubert, M., Keefe, D., McGuire, D., Epstein, J., Elting, L., Fox, P., Cooksley, C. \& Sonis, S., 2004, 'Clinical practice guidelines for the prevention and treatment of cancer therapy-induced oral and gastrointestinal mucositis', Cancer 100, 2026-2046, viewed 7 February 2012, from http://dx.doi. org/10.1002/cncr.20163, PMid:15108223

Sieracki, R., Johannik, T., Kopaczewski, D. \& Hubert, K., 2009, 'Development and implementation of an oral care protocol for patients with cancer', Clinical Journal of Oncology Nursing 13, 718-722, viewed 7 February 2012, from http://dx.doi. org/10.1188/09.CJON.718-722, PMid:19948471

Sonis, S., 2007, 'Pathobiology of oral mucositis: novel insights and opportunities', Journal of Supportive Oncology 9, 3-11.

Sonis, S., Clairmont, F., Lockhart, P. \& Connolly, S., 1985, 'Benzydamine HCL in the management of chemotherapy-induced mucositis. I. Pilot study', Journal of Ora Medicine 40, 67-71. PMid:3858465

Sonis, S., Elting, L., Keefe, D., Peterson, D., Schubert, M., Hauer-Jensen, M., Bekele, B. Raber-Durlacher, J., Donnelly, J. \& Rubenstein, E., 2004, 'Perspectives on cancer therapy-induced mucosal injury', Cancer 100, 1995-2025, viewed 7 February 2012, from http://dx.doi.org/10.1002/cncr.20162, PMid:15108222

The Johanna Briggs Institute, 2010, 'Chemotherapy: Mucositis management', viewed 1 October 2011, from http://connect.jbiconnectplus.org/ViewDocument. aspx?0 $=2074$

Volpato, L., Silva, T., Oliveira, T., Sakai, V. \& Machado, M., 2007, 'Radiation therapy and chemotherapy-induced oral mucositis', Revista Brasileira de Otorrinolaringologia 73, 562-568, viewed 15 April 2011, from http://dx.doi.org/10.1590/S003472992007000400017, PMid:17923929

Witt, M., 2007, 'Mucositis', in M. Haas, W. Hogle, G. Moore-Higgs, T. Gosselin-Acomb, (eds.), Radiation Therapy: A guide to patient care, pp. 563-573, Mosby, St Louis.

Worthington, H., Clarkson, J., Bryan, G., Furness, S., Glenny, A., Littlewood, A. McCabe, M., Meyer, S. \& Khalid, T., 2011, 'Interventions for preventing oral mucositis for patients with cancer receiving treatment', Cochrane database of systematic reviews 4 .

Wu, J., Beale, K. \& Ma, J., 2010, 'Evaluation of current and upcoming therapies in oral mucositis prevention', Future Oncology 6, 1751-1770, viewed 7 February 2012 from http://dx.doi.org/10.2217/fon.10.133, PMid:21142661 